\title{
Chemical characterization of oils produced by some native and introduced genotypes of argan tree in eastern Morocco using HPLC-DAD/GC-MS, and the evaluation of their physicochemical parameters
}

\author{
Salah-eddine Azizi ${ }^{1, *}$, Mohammed Dalli ${ }^{1}$ (D), Ibtissam Mzabri ${ }^{2}$ (D), Abdelbasset Berrichi ${ }^{2}$ \\ and Nadia Gseyra ${ }^{1}$ \\ ${ }^{1}$ Laboratory of Bioresources, Biotechnology, Ethnopharmacology and Health, Department of Biology, Faculty of Sciences, Mohammed \\ First University of Oujda, Oujda, Morocco \\ ${ }^{2}$ Laboratory of Agricultural Production Improvement, Biotechnology and Environment, Department of Biology, Faculty of Sciences, \\ Mohammed First University of Oujda, Oujda, Morocco
}

Received 3 January 2022 - Accepted 1 February 2022

\begin{abstract}
The argan tree is an endemic plant of Morocco that plays a great socio-economical and ecological impact in the south of the country. This plant is well known for the oil extracted from the almond, characterized by high nutritional value and its large spectrum of uses. This study aims to evaluate the chemical composition and the physicochemical parameters of fixed oils produced by the argan trees introduced in Oujda City and to compare them with other oils produced by the same trees in their natural biotope in the northeast and southwest of Morocco. The obtained results indicated that the oil yield varies between $57.65 \%$ and $47.60 \%$. The investigation of the chemical composition using HPLC-DAD showed the presence of three types of tocopherols: $\alpha$-tocopherols $(9.7 \%), \delta$-tocopherols $(6.6 \%)$, and $\gamma$-tocopherols $(83.6 \%)$, the total content of tocopherols vary between 323.86 and $553.12 \mathrm{mg} / \mathrm{kg}$. While, the methyl esters analysis using GC-MS showed the presence of 4 main fatty acids: oleic acid (55.40-41.14\%), linoleic acid (36.92-26.75\%), palmitic acid (18.69-9.97\%) and stearic acid (12.09-3.68). The physicochemical parameters (the free acidity, the peroxide value, and the specific extinction) indicated that the different tested oils are characterized by a good oil quality according to the Moroccan standard concerning argan oil (NM 08.5.090). The obtained results indicated that the introduced argan in Oujda City showed a quality and a chemical composition that was comparable to that produced in the natural area of the argan tree, which shows the plasticity the plant under different climatic and edaphic conditions. These results emphasize the encouragement of the introduction of this species at a high level in eastern Morocco.
\end{abstract}

Keywords: argan oil / introduced argan tree / chemical composition / physicochemical parameters / eastern Morocco

Résumé - Caractérisation chimique des huiles produites par quelques génotypes natifs et introduits de l'arganier au Maroc oriental par HPLC-DAD/GC-MS, et évaluation de leurs paramètres physicochimiques. L'arganier est une plante endémique du Maroc qui joue un grand rôle socio-économique et écologique dans le sud-ouest du pays. Cette plante est bien connue pour l'huile extraite de ses amandes, qui est caractérisée par une valeur nutritionnelle élevée et une multitude d'utilisations. Cette étude vise à évaluer la composition chimique et les paramètres de qualité physico-chimiques des huiles fixes produites par les arganiers introduits dans la ville d'Oujda et à les comparer avec d'autres huiles produites par les mêmes arbres dans leur biotope naturel au nord-est et au sud-ouest du Maroc. Les résultats obtenus indiquent que le rendement en huile varie entre 57,65 et 47,60\%. L'étude de la composition chimique par HPLC-DAD a montré la présence de trois types de tocophérols: $\alpha$-tocophérols $(9,7 \%), \delta$-tocophérols $(6,6 \%)$, et $\gamma$-tocophérols $(83,6 \%$ ), la teneur totale en tocophérols varie entre 323,86 et $553,12 \mathrm{mg} / \mathrm{kg}$. Tandis que l'analyse des esters méthyliques par GC-MS a montré la présence de 4 principaux acides gras: l'acide

*Correspondence: azizi.salah-eddine@ump.ac.ma 
oléique (55,40-41,14\%), l'acide linoléique (36,92-26,75\%), l'acide palmitique (18,69-9,97\%) et l'acide stéarique (12,09-3,68\%). Les paramètres physico-chimiques (l'acidité libre, l'indice de peroxyde, et l'extinction spécifique) montrent que les différentes huiles testées sont caractérisées par une bonne qualité d'huile selon la norme marocaine concernant l'huile d'argan (NM 08.5.090). Les résultats obtenus indiquent que l'huile produite par l'arganier introduit dans la ville d'Oujda présente une qualité et une composition chimique comparables à celles produites par l'arganier dans son biotope naturel, ce qui montre la plasticité de cette plante face aux différentes conditions climatiques et édaphiques. Ces résultats encouragent l'introduction de cette espèce à un niveau élevé dans le Maroc oriental.

Mots clés : huile d'argan / arganier introduit / composition chimique / paramètres physico-chimiques / Maroc oriental

\section{Introduction}

Argan tree scientifically named Argania spinosa is an endemic plant of Morocco, belonging to the Sapotaceae family (Rammal et al., 2009). This native species is concentrated mainly in the southwest and exists as a relic in the northeast and the west of the country (Tazi et al., 2003; Faouzi et al., 2014; Moukrim et al., 2018). Side to side with holm oak and cedar, the argan constitute an essential species of the Moroccan forest (Chaussod et al., 2005), and the vast area covered by argan trees in the south of Morocco was designated a UNESCO biosphere reserve in 1998 (Mohammed et al., 2021). This tree is endowed with a great socio-economical and ecological impact (Bellefontaine et al., 2010). The argan oil is considered among the main product obtained from the plant kernels and is well known worldwide for its nutritional value (Mechqoq et al., 2021b), which gives the oil a large use not only for its nutritional value but also for its various health benefits (Boukhobza and Pichon-Prun, 1988). Traditionally, the oil constitutes the main element in the different gastronomic preparations of the Amazigh population living in the southwest of Morocco. In cosmetics, the oil is used as a moisturizer and for the care of different body parts and hair (Charrouf et al., 2002; Moukal, 2004; Charrouf and Guillaume 2010). Recently, the argan oil was found to be endowed with important biological activities especially, antidiabetic (Daoudi et al., 2020; Kamal et al., 2021), anticancer (Drissi et al., 2006), and anti-inflammatory activity (Kamal et al., 2019). These different virtues and benefits of argan oil could be attributed to its richness in tocopherols, unsaturated fatty acids (oleic acid), and phenolic compounds (Marfil et al., 2011). The chemical composition of the argan oil is essentially formed by two fractions, a saponified fraction which represents $99 \%$ and is characterized by the presence of a high amount of unsaturated fatty acids such as oleic acid (45-50\%) and linoleic acid (30-35\%) (El Kharrassi et al., 2018; Zaaboul et al., 2018). While, the unsaponified fraction represents $1 \%$ and is formed by chemical components such as polyphenols, sterols, and tocopherols (Charrouf and Guillaume, 2008). The global demand for the oil increases and this is due to the different virtues and nutritional quality, but parallelly this species knows a regression, despite its high tolerance to the extreme climate as well as its plasticity towards the climatic conditions. This is caused mainly by the climatic changes, overgrazing as well as overexploitation, which implies the conservation of the population of the argan tree by increasing the reforestation and introduction of this species at a large scale.
This work is a preliminary study which aims to characterize the phytochemical variability and to evaluate the physicochemical properties of oils obtained from argan different genotypes introduced to Oujda City in comparison to some native trees of eastern Morocco (Beni-Znassen Mountain range) and those southwest of Morocco (Agadir).

\section{Material and methods}

\subsection{Plant material}

The planted argan trees in Oujda City are resulting from seeds propagation that was raised in the nursery of the faculty of sciences, Oujda until their suitability for transplantation ( 2 years). Then they were planted in 2011 in the different green spaces of the same faculty, and in Oujda City. The introduced argan trees are named as follow $(\mathrm{O}-1, \mathrm{O}-2, \mathrm{O}-3, \mathrm{O}-4, \mathrm{O}-5, \mathrm{O}-6$, $\mathrm{O}-7, \mathrm{O}-8)$. The fruits were harvested during the maturation process of each genotype, and this during May and June 2020. The geographic location is depicted in Figure 1.

Six genotypes representing the argan grove of Beni-Znassen Mountains that were named as follow (CH-1, $\mathrm{CH}-2, \mathrm{CH}-3, \mathrm{CH}-4, \mathrm{CH}-5, \mathrm{CH}-6)$. The fruits were harvested in June 2020 and the geographic location of the studied genotypes is depicted in Figure 2.

Finally, two genotypes originating from the southwest of Morocco particularly located at the anti-atlas, near Taroudant City at the following location (AG-1: 30.6337755, -8.8271660), and (AG-2: 30.6322814, -8.8283253) the fruits were collected in June 2020.

The results drafted in Table 1 show some morphological characteristics of the studied genotypes such as the shape of the tree and the fruits.

\subsection{Sampling plan}

The sampling plan adopted is based on several criteria such as production, the stability of the production and rentability. A total of 100 genotypes originating from Oujda and Chouihya were followed up during 3 years and the interesting genotypes were adopted for the evaluation of their oils physicochemical parameters. The two genotypes from Agadir were chosen randomly just for the comparison.

\subsection{Climatic characteristics}

The climatic characteristics of the different regions are represented in Table 2. The climatic parameters collected 


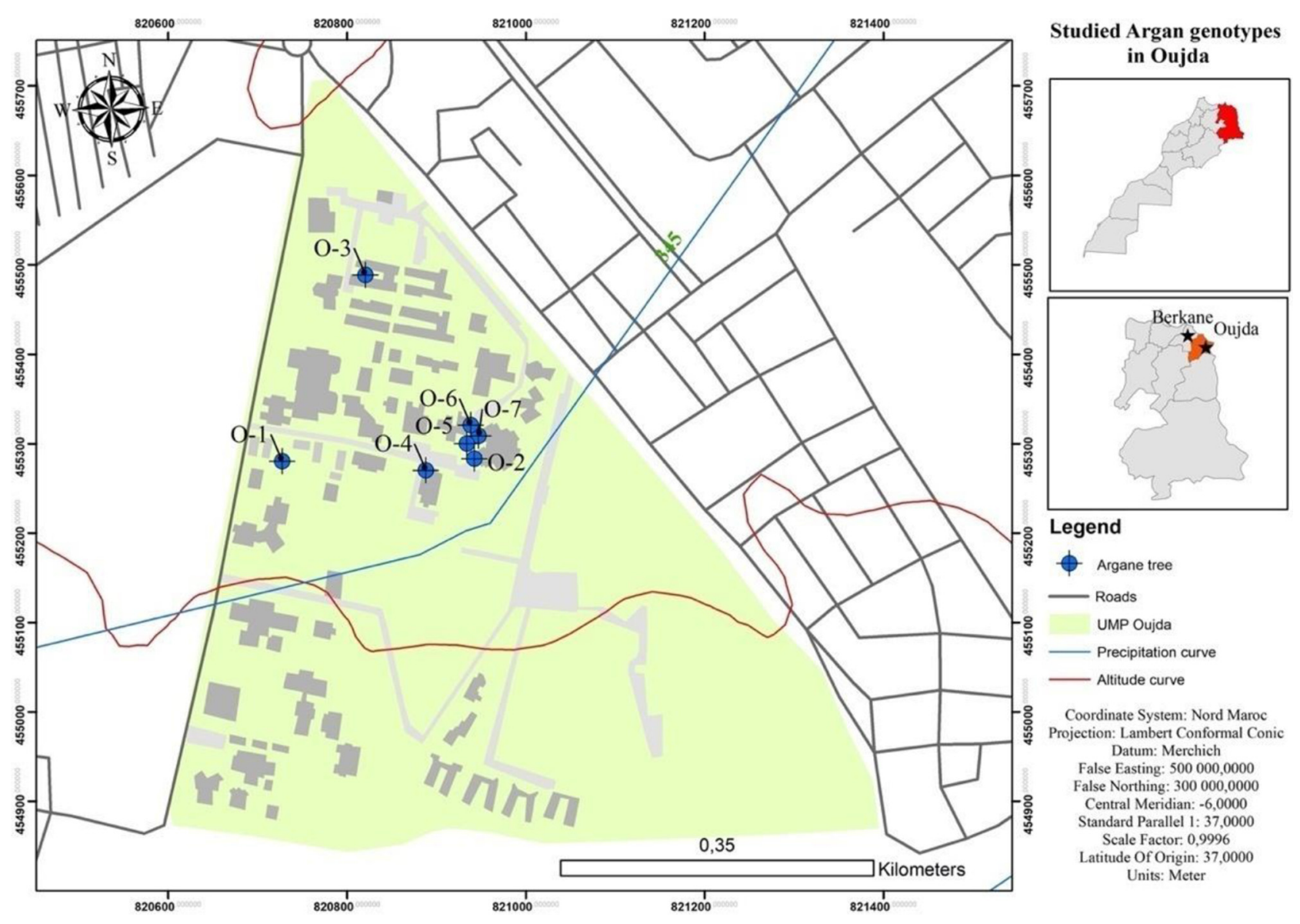

Fig. 1. Location of studied Argania spinosa L. Skeels tree in Oujda.

represent the average minimum, maximum temperature, annual precipitation, altitude and bioclimatic stage in the regions concerned by the study (climatic data was obtained from Terra climate dataset which provides a climate and climatic water balance data for global terrestrial surfaces from 1958 to present) (Abatzoglou et al., 2018).

\subsection{Preparation and extraction of the argan fixed oil}

\subsubsection{Harvesting process and almonds preparation}

The mature fresh fruits of the A. spinosa were harvested periodically during their maturity period (May and June 2020) with about $3 \mathrm{~kg}$ of fresh fruits from each tree. After that, the different collected fruits were kept in a dark room to be naturally dried for approximately 10 days. Finally, the fully dried fruits were subject to followed pulping, and to crushing to extract the almonds.

\subsubsection{Oil extraction}

Before proceeding with the oil extraction, the almonds were put in the oven for $24 \mathrm{~h}$ at a temperature of $35^{\circ} \mathrm{C}$ until a total dryness. After that, $50 \mathrm{~g}$ of the dried kernels were turned into a fine powder that was subject to a chemical extraction in a Soxhlet apparatus using $\mathrm{n}$-hexane $(250 \mathrm{ml})$ as an extraction solvent. The extraction process lasted about $3 \mathrm{~h}$ until total exhaustion of the plant material. The rotary evaporator was used for the total elimination of the extraction solvent. Once recovered, the oils were put in opaque glass bottles of $30 \mathrm{ml}$ and stored at $-20^{\circ} \mathrm{C}$ until further use. All experiments were carried out in triplicate and data was expressed as the mean $\pm \mathrm{SD}$.

\subsection{Tocopherols quantification using HPLC-DAD}

The different tocopherols isomers $(\alpha, \delta, \gamma)$ were separated and identified using the methods described by Ben Moumen et al. (2015). The oils were dissolved in hexane $(0.5 / 0.5 \mathrm{~W} / \mathrm{W})$ and was analyzed using an HPLC apparatus (Shimadzu LC-6AD system) equipped with a DAD detector. The tocopherols were separated using Uptisphere $120 \AA \mathrm{NH}_{2}$ column $(150 \times 3 \mathrm{~mm}, 3 \mu \mathrm{m})$ Interchim (Montluçon, France), the solvent system used was hexane/2-propanol $(99: 1, \mathrm{~V} / \mathrm{V})$ eluted at a flow rate of $1 \mathrm{~mL} \cdot \mathrm{min}^{-1}$, and the injection volume was $20 \mu \mathrm{L}$. The identification was carried out using commercial standards for tocopherols (Sigma-Aldrich, St-Louis, USA) at 292, 296, and $298 \mathrm{~nm}$. The tocopherol concentration was calculated from the external calibration curve with commercial tocopherols obtained from Sigma-Aldrich (St-Louis, MO, USA). All experiments were carried out in triplicate and data was expressed as the mean $\pm \mathrm{SD}$. 


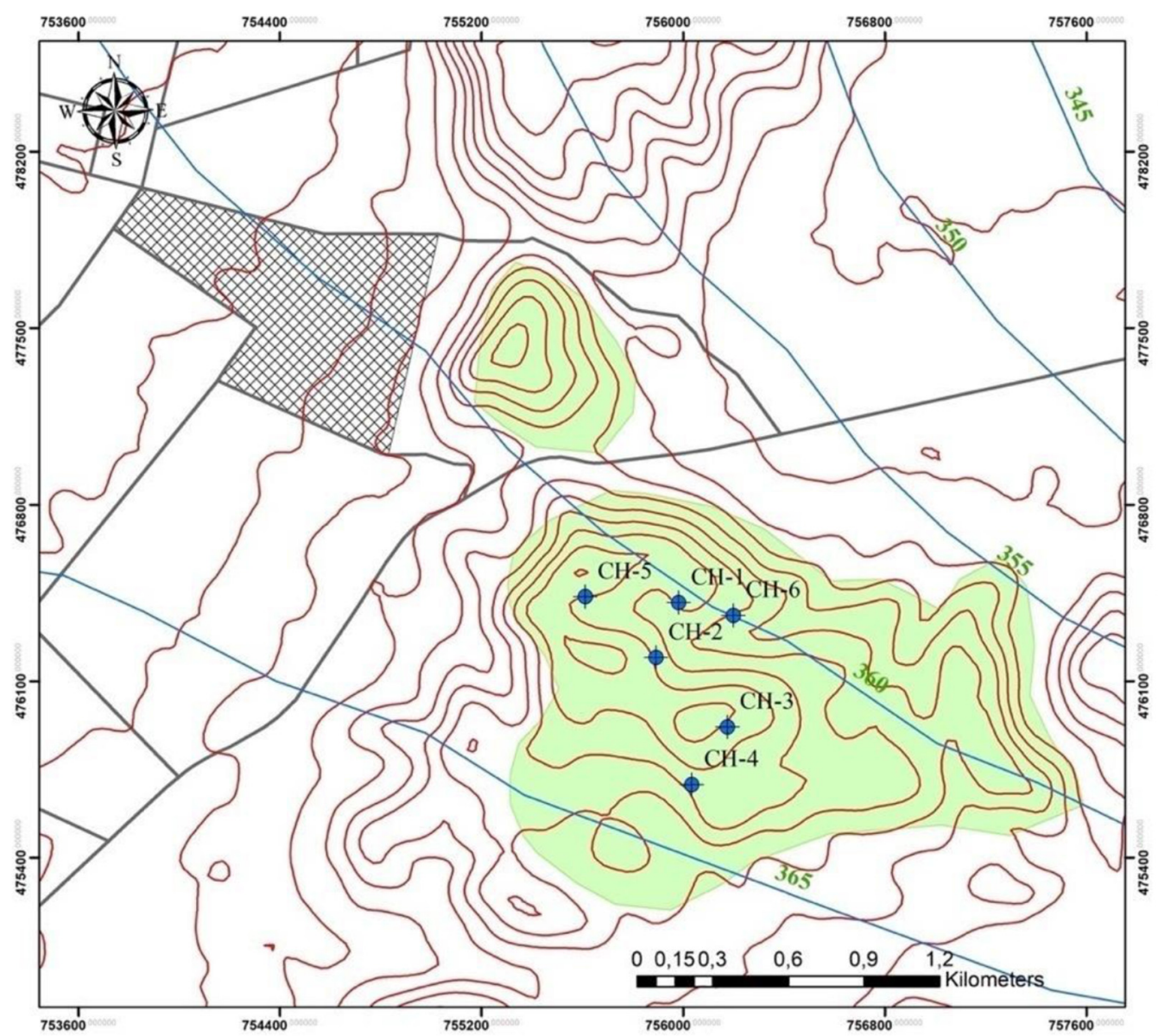

Studied Argan genotypes from Beni-Znassen

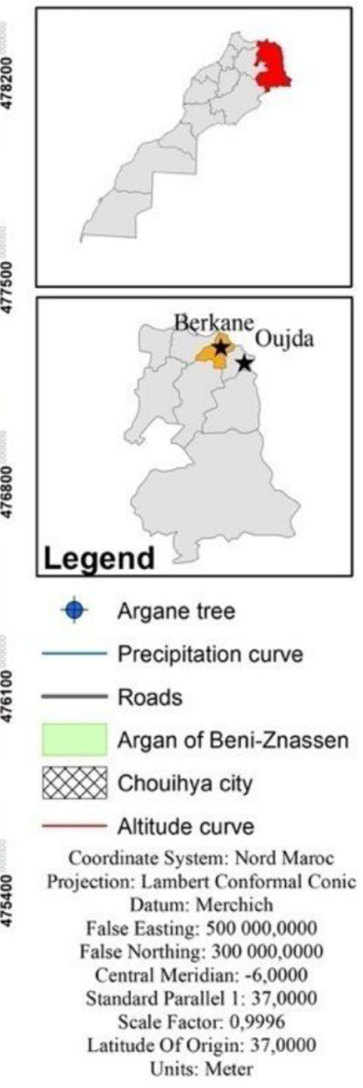

Fig. 2. Geographical location of studied A. spinosa L. Skeels tree in the west of Beni-Znassen Mountains.

Table 1. Morphological characteristics of the studied genotypes.

\begin{tabular}{lllll}
\hline Origin & Genotypes & Age (years) & Shape & Fruits form \\
\hline \multirow{6}{*}{ Oujda } & O-1 & 10 & Spreading & Spherical \\
& O-2 & 10 & Upright & Oval \\
& O-3 & 10 & Upright & Oval \\
& O-4 & 10 & Drooping & Oval \\
& O-5 & 10 & Drooping & Spherical \\
& O-6 & 10 & Spreading & Oval \\
& O-7 & 10 & Upright & Spherical \\
& O-8 & 10 & Upright & Spherical \\
CH-1 & $>50$ & Spreading & Oval \\
Chouihiya & CH-2 & $>50$ & Drooping & Spherical \\
& CH-3 & $>50$ & Drooping & Oval \\
& CH-4 & $>50$ & Spreading & Oval \\
Agadir & CH-5 & $>50$ & Spreading & Fisuform \\
& CH-6 & $>50$ & Spreading & Oval \\
& AG-1 & $>50$ & Spreading & Fusiform \\
\hline
\end{tabular}


Table 2. Climatic characteristics of the study areas.

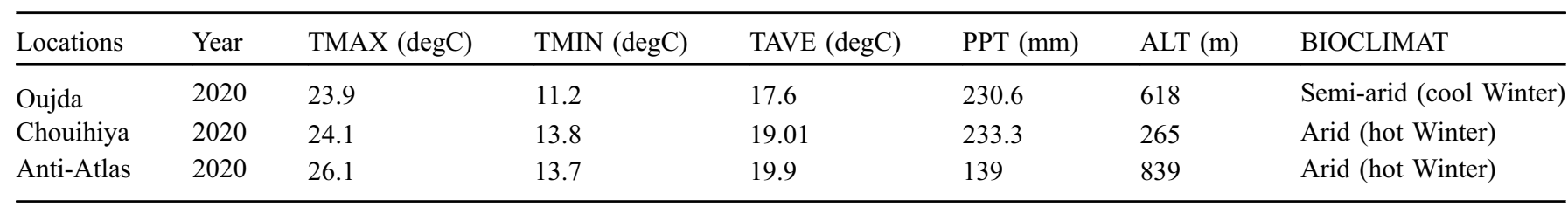

\subsection{Qualitative and semi-quantitative Fatty acid analysis using GC-MS}

The methyl ester preparation was assessed following the protocol of the standard NF T60-233. The esterified hexane extracts were the subject of chemical analysis using the Gaz Chromatography (Shimadzu GC-2010) supplied with a fusedsilica capillary column that is directly related to mass spectrometer detector (GC-MS-QP2010). After the helium pressure was adjusted to $100 \mathrm{kPa}$. This was followed by a regulation of the oven temperature of $50{ }^{\circ} \mathrm{C}$ (maintained for 1 minute) initially, followed by a gradient of $10^{\circ} \mathrm{C} / \mathrm{min}$ up to $250{ }^{\circ} \mathrm{C}$ (maintained for 1 minute). Concerning the qualitative and semi-quantitative, $1 \mu \mathrm{l}$ was taken from the original samples, then diluted in hexane $(50 \mathrm{mg} / \mathrm{g})$, and finally injected in split mode (split ratio $=50-80$ ). The mass spectra were recorded at $70 \mathrm{eV}$ (electron impact ionization mode) with an $\mathrm{m} / \mathrm{z}$ range of 40-350 a.m.u. (rate and solvent delays were $5 \mathrm{~s} / \mathrm{scan}$ and 4.5 minutes, respectively). The identification of the different obtained peaks was accomplished by the comparison of the obtained MS data with that stored at the library of the National Institute of Standards and Technology (NIST147). LabSolutions (version 2.5) was used for data collection and processing. All experiments were carried out in triplicate and data was expressed as the mean $\pm \mathrm{SD}$.

\subsection{Physicochemical analysis}

The acid value and peroxide value were determined according to the Codex Standard 210-1999 (Alimentarius Codex, 1999). Specific extinction was determined according to the official analytical method (ISO 3656:2002) (Organisation Internationale de Normalisation, 2002). All experiments were carried out in triplicate and data was expressed as the mean \pm SD.

\subsection{Statistical analysis}

The results obtained were subjected to descriptive statistical analysis and an analysis of the variance (ANOVA), using the software "SPSS for Windows version 23" followed by the Tukey test with post hoc multiple comparisons threshold of $5 \%$. The oil content and the different chemicals components such as fatty acids and tocopherols contents were subjected to hierarchical cluster analysis (HCA) and principal component analysis (PCA) using the same software. In the case of HCA, the dendrogram (tree) was produced using Ward's method of hierarchical clustering with squared Euclidean distance between oil samples. All experiments were carried out in triplicate, and data were expressed as the mean $\pm \mathrm{SD}$.
Table 3. Oil content of argan seeds of the studied genotypes cultivated in three regions of Morocco.

\begin{tabular}{lll}
\hline Origin & Genotypes & Oil content $(\%)$ \\
\hline \multirow{6}{*}{ Oujda } & $O-1$ & $\mathbf{5 5 . 1 6} \pm 1.10^{\mathrm{g}}$ \\
& $O-3$ & $\mathbf{5 3 . 5 3} \pm 0.62^{\mathrm{ef}}$ \\
& $O-4$ & $\mathbf{4 8 . 2 3} \pm 0.88^{\mathrm{ab}}$ \\
& $O-5$ & $\mathbf{4 7 . 6 0} \pm 0.55^{\mathrm{a}}$ \\
$O-6$ & $\mathbf{5 3 . 7 0} \pm 0.61^{\mathrm{f}}$ \\
$O-7$ & $\mathbf{4 8 . 2 6} \pm 0.56^{\mathrm{ab}}$ \\
& $O-8$ & $\mathbf{5 3 . 8 5} \pm 0.84^{\mathrm{f}}$ \\
& $C H-1$ & $\mathbf{5 1 . 8 6} \pm 0.81^{\mathrm{d}}$ \\
& $C H-2$ & $\mathbf{5 2 . 0 0} \pm 0.86^{\mathrm{d}}$ \\
& $C H-3$ & $\mathbf{5 7 . 6 5} \pm 0.50^{\mathrm{h}}$ \\
Chouihiya & $C H-4$ & $\mathbf{5 3 . 7 8} \pm 0.45^{\mathrm{f}}$ \\
& $C H-5$ & $\mathbf{4 9 . 4 0} \pm 0.47^{\mathrm{bc}}$ \\
& $A G-1$ & $\mathbf{4 8 . 5 9} \pm 0.55^{\mathrm{abc}}$ \\
Agadir & $A G-2$ & $\mathbf{4 9 . 6 9} \pm 0.78^{\mathrm{c}}$ \\
& & $\mathbf{5 0 . 2 9} \pm 0.47^{\mathrm{d}}$ \\
& & $\mathbf{5 2 . 4 3} \pm 0.49^{\mathrm{de}}$ \\
\hline
\end{tabular}

Values followed by different letters are significantly different $(P<0.05)$.

Values with the same letters indicate no significant difference $(P>0.05)$.

\section{Results}

\subsection{Oil content}

The oil content of the different samples is depicted in Table 3, and it varies between $47.61 \%$, and $57.65 \%$ according to the genotypes and the origins. The genotype named $\mathrm{CH}-2$ was found to have the highest oil content, while the O-6 Oujda genotype recorded the lowest oil content of about $48.23 \%$.

Regarding the average of the oil content for each region, it was registered $51.85 \%$ for the genotypes originated from Chouihya followed by those from Oujda with a value of $51.52 \%$. Finally, the Agadir genotypes oil content was $51.36 \%$.

The statistical analysis of the variance showed the existence of a significant difference between the different genotypes $(<0.05)$, while no significant difference was noticed between the regions $(p>0.05)$.

\subsection{Physicochemical parameters}

The spectrophotometric examination allowed us to calculate the specific extinction at 230 and $270 \mathrm{~nm}$, and also 
Table 4. Specific extinction, free acidity (\%) and peroxide index $\left(\mathrm{Meq}_{2} / \mathrm{kg}\right)$ of argan seeds oil of the studied genotypes cultivated in three regions of Morocco.

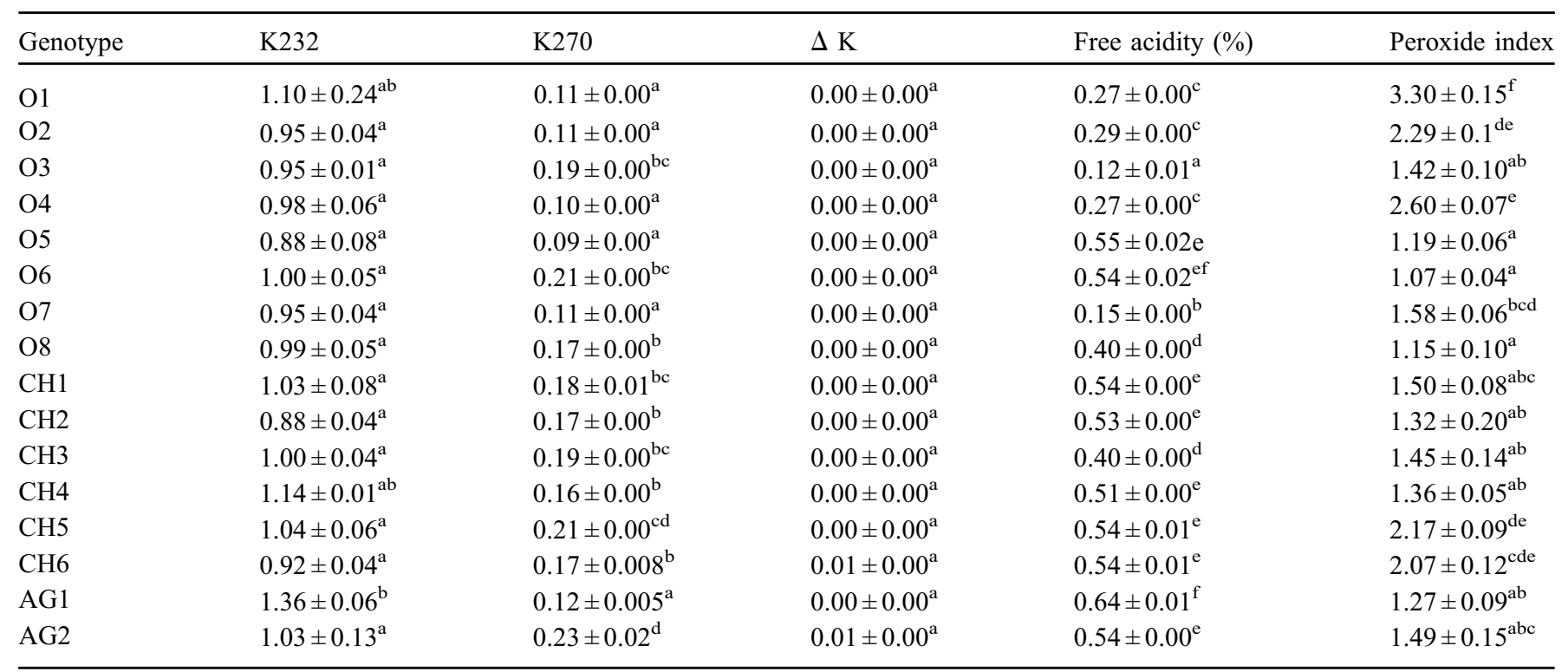

Values followed by different letters are significantly different $(P<0.05)$.

Values with the same letters indicate no significant difference $(P>0.05)$.

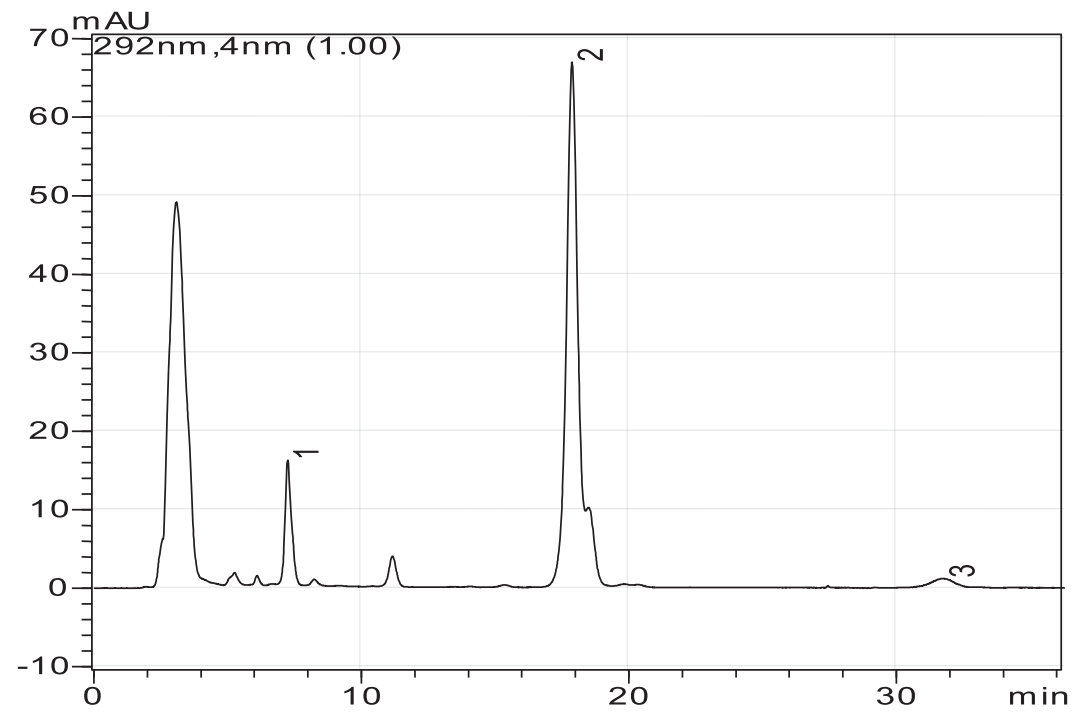

Fig. 3. Example of the chromatogram of the A. spinosa seeds oil tocopherols obtained using the HPLC-DAD. (1: $\alpha$-tocopherol; 2 : $\gamma$-tocopherol; 3: $\delta$-tocopherol).

to calculate $\Delta \mathrm{K}$ of the oils produced by the different genotypes. The obtained results are depicted in Table 4.

Concerning the specific extinction at $232 \mathrm{~nm}$, the results showed a maximum of 1.362 for AG-1 and a minimum of 0.882 for $\mathrm{CH}-2$. Concerning the specific extinction at $272 \mathrm{~nm}$ the values were ranging from $0.09(\mathrm{O}-5)$ to 0.226 (AG-2). Finally, the $\Delta \mathrm{K}$ corresponding to the difference of the specific extinction registered a maximum value of 0.01 by AG-2 and CH-6 genotypes.
Regarding the free fatty acids content, it was found to vary between $0.12 \%$ (O-3) to $0.64 \%$ (AG-1). As depicted in Table 3, the values obtained for the peroxide index were ranging from 1.07 recorded by O- 6 and 3.30 meq $_{2} / \mathrm{kg}$ by O- 1 .

The statistical analysis indicated the existence of a significant difference between the different studied genotypes. It was also showed the existence of homogenous subgroups $(p<0.05)$, but these values are still under the threshold established by the Moroccan standard concerning argan oil (NM 08.5.090) (Moroccan Standard, 2003). 
Table 5. Tocopherols content (mg/kg) of different A. spinosa seeds oil of the studied genotypes cultivated in three regions of Morocco.

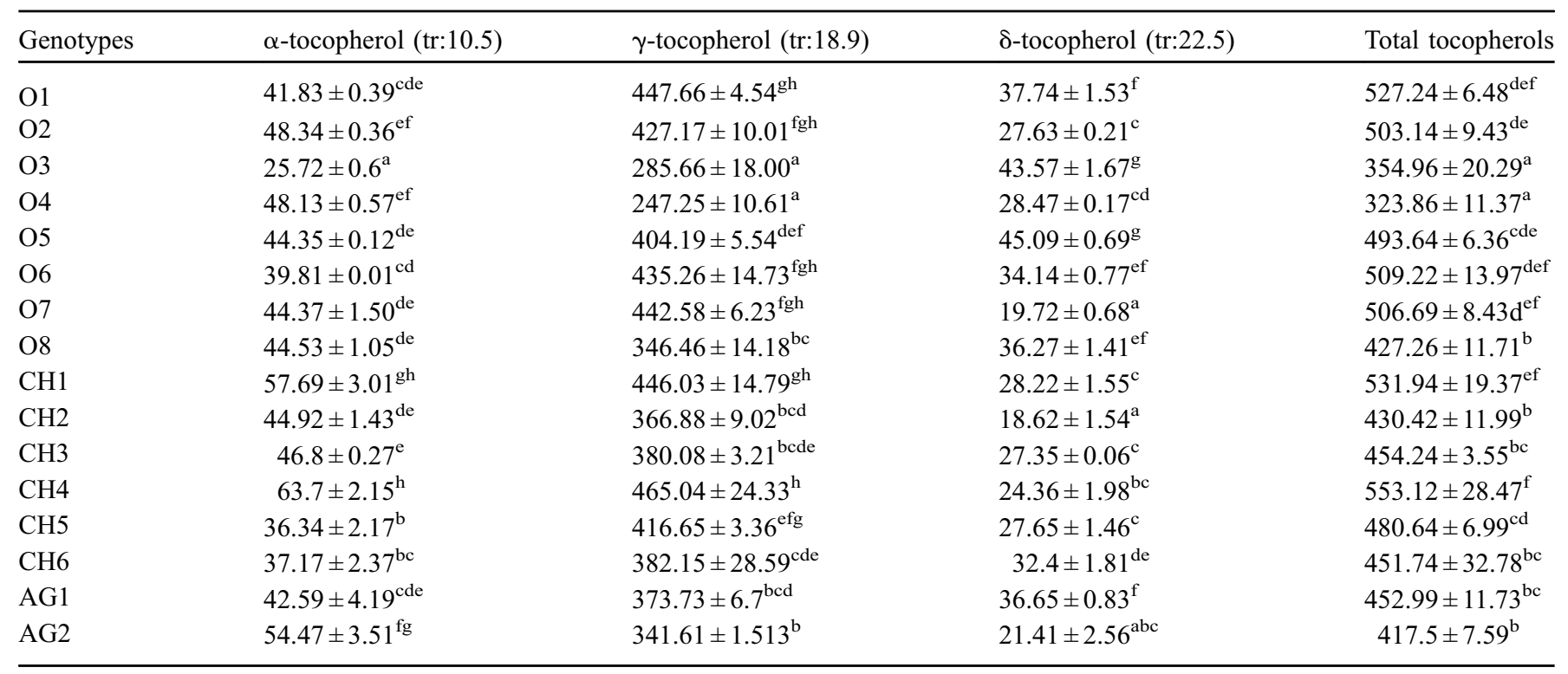

Values followed by different letters are significantly different $(P<0.05)$.

Values with the same letters indicate no significant difference $(P>0.05)$.

\subsection{Tocopherols content}

The HPLC-DAD analysis showed that argan oils resulting from different genotypes of the three studied regions are rich in tocopherols and are composed mainly of 3 isomers (Fig. 3 and Tab. 5). $\gamma$-tocopherols are found to be the most abundant, followed by $\alpha$-tocopherols, and $\delta$-tocopherols.

The total tocopherols content varies between $553.12 \pm 28.47 \mathrm{mg} / \mathrm{kg}$ and $323.86 \pm 11.37 \mathrm{mg} / \mathrm{kg}$. Concerning the quantity of the different isomers. As noted, the $\gamma$-tocopherols have the largest part and they vary between $465.04 \pm 23.33 \mathrm{mg} / \mathrm{kg}$ and $247.25 \pm 1.61 \mathrm{mg} / \mathrm{kg}$ followed by the $\alpha$-tocopherols with a quantity that varies between $63.7 \pm 2.15 \mathrm{mg} / \mathrm{kg}$ and $25.72 \pm 0.60 \mathrm{mg} / \mathrm{kg}$. Finally, the $\delta$-tocopherols had the smallest amount of all identified tocopherols and vary among $45.09 \pm 0.69$ and $18.62 \pm 1.54 \mathrm{mg} / \mathrm{kg}$.

Concerning the genotype, the $\mathrm{CH}-4$ showed the highest content of total tocopherols, $\alpha$-tocopherols, and $\gamma$-tocopherols. While O-5 was the richest one with the $\delta$-tocopherols. On the other hand, 5 introduced genotypes have shown higher total tocopherols content, which was superior to $500 \mathrm{mg} / \mathrm{kg}$, (O-1; O-2; O-6; O-7).

The ANOVA variance analysis indicated the existence of a statistical difference between the different genotypes $(p<0.05)$. On the other hand, post hoc multiple comparisons allowed the differentiation of homogenous subgroups.

\subsection{Fatty acids composition}

The GC-MS analysis drafted in Table 6 revealed the existence of four main fatty acids in the different analyzed samples (palmitic acid, linoleic acid, oleic acid, and stearic acid).

The oleic acid was the most dominant compound with a percentage ranging from $41.14 \%$ to $55.40 \%$ followed by the linoleic acid that varies between $26.75 \%$ and $36.92 \%$. While the palmitic acid percentage varies between $9.97 \%$ and $18.69 \%$. Finally, the stearic acid was less found in the different samples with a percentage of $3.68 \%$ to $12.09 \%$. On the other side, the richness of the oil samples with oleic and linoleic acids is translated by the increase of the unsaturated fatty acid percentage, which is over $70 \%$ for all tested samples with a maximum value of $83.88 \%$. Regarding the saturated fatty acids, the percentage was ranging between $16.16 \%$ and $25.79 \%$.

The genotype $\mathrm{CH}-2$ has recorded the highest percentage of oleic acid, while the highest rate of linoleic acid was recorded in O-6, O-8, and O-7 genotypes. In addition, the genotypes named O-7, and O-4 had respectively the highest amounts with the palmitic acid rate. Finally, the highest percentage of palmitic acid was registered by the genotype named AG-1.

The statistical analysis demonstrated the existence of a significant difference between the different studied genotypes $(p<0.5)$. Also, the different genotypes were classed into subgroups.

\subsection{PCA and HCA analysis}

The different identified chemical compounds using the GC-MS were subject to hierarchical cluster (HCA) followed by principal component analysis (PCA) to determine the existing relation between the different chemicals parameters, and to illustrate the existing chemical variability between all studied samples.

The results drawn in Figures $4 \mathrm{~A}$ and $4 \mathrm{~B}$ revealed that the (PC1) and (PC2) represented $52.28 \%$ of the total variance. The first component (PC1) accounted for $32.63 \%$ of the total variance and was correlated positively with the $\gamma$-tocopherols, total tocopherols, $\alpha$-tocopherols, linoleic acid, and oil content, while it was found to be correlated negatively with the 
Table 6. Main fatty acids composition of argan seeds oil of the studied genotypes cultivated in three regions of Morocco (\% of the main fatty acids).

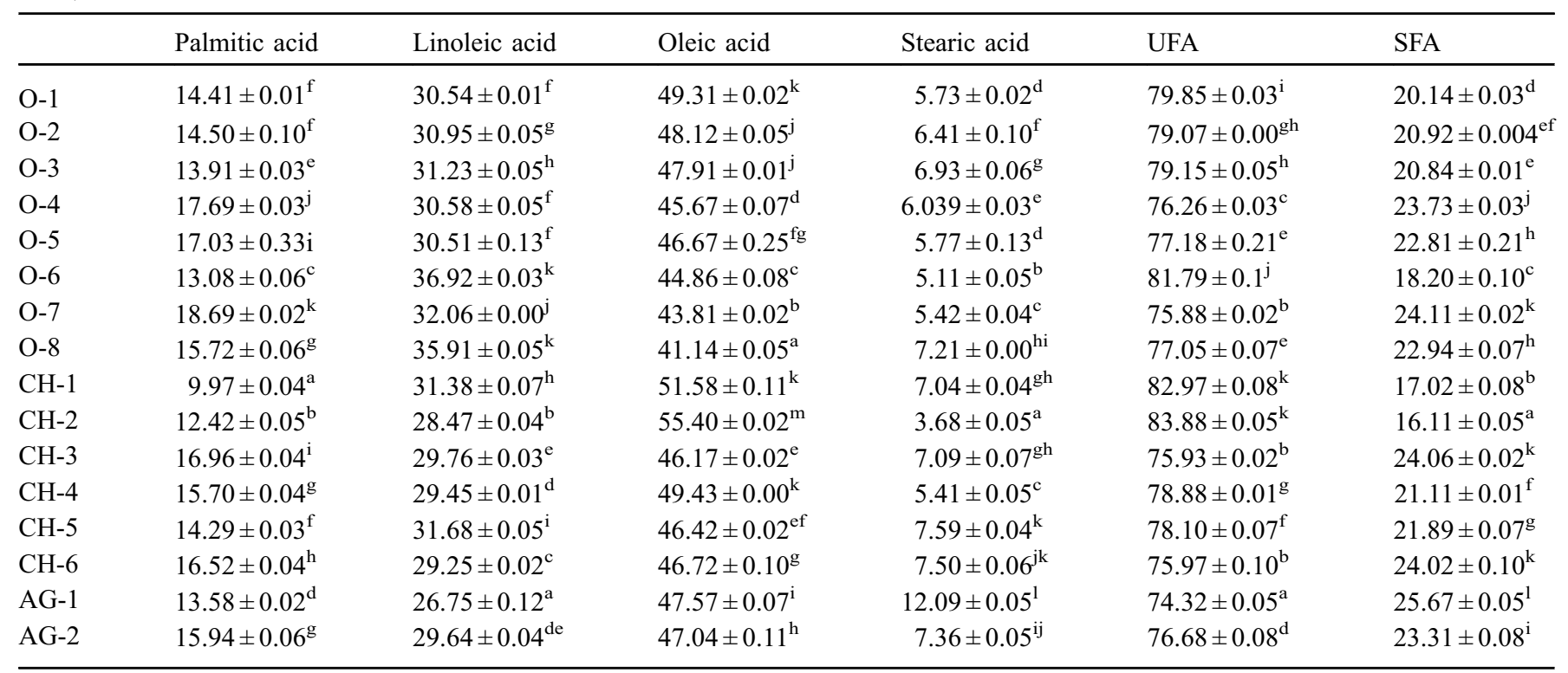

UFA: Unsaturated fatty acids SFA: saturated fatty acid.

Values followed by different letters are significantly different $(P<0.05)$ values with same letters indicate no significant difference $(P>0.05)$.

$\delta$-tocopherols and the palmitic acid content. On the other side, the second principal component (PC2) accounted for $19.65 \%$ was found to be correlated positively with linoleic acid, $\gamma$-tocopherols. While correlated negatively with stearic and oleic acids.

Regarding the genotypes distribution (Fig. 4), the O-6 and O-5 were positively aligned to the axis of the second component, which is strongly correlated to linoleic acid and $\delta$-tocopherols, these genotypes were found to be the richest in linoleic acid and $\delta$-tocopherols. On the counterpart, the genotypes AG-1, AG-2, and $\mathrm{CH}-3$ were the richest in stearic acid.

The genotypes $\mathrm{CH}-1, \mathrm{O}-2, \mathrm{O}-1, \mathrm{CH}-4$, and $\mathrm{CH}-2$ were positively aligned to the axis of the first component, which highlights their richness in $\alpha$-tocopherols, total tocopherols; oleic acid or high oil content, and low content of palmitic and stearic acids. On the other hand, the genotypes O-3, and O-4 are negatively aligned to the axis of the first component and are characterized by low oil content, as well as a content of total tocopherols and $\gamma$-tocopherols that is very low.

The dendrogram drafted in Figure 5 produced by hierarchical cluster analysis based on Euclidean distances shows that the different genotypes can be classified into 6 main clusters (at a distance of 5 units), which shows that there is a significant difference in the chemical composition of A. Spinosa genotypes. The samples linked by short distances are more similar than those connected by large ones.

The first cluster is represented by 4 genotypes $(\mathrm{O}-1, \mathrm{O}-2$, $\mathrm{CH}-4$, and $\mathrm{CH}-1)$. These genotypes are characterized by an interesting oil content (up to 55\%) as well as a high content of $\alpha$-tocopherols ( $\leq 67 \mathrm{mg} / \mathrm{kg}), \gamma$-tocopherols $(>400 \mathrm{mg} / \mathrm{kg})$ and important total-tocopherols content $(>520 \mathrm{mg} / \mathrm{kg})$. Finally, their oleic acid content was high (48-51\%).
CH-2 sample was found to construct the second cluster. This latter is characterized by a very high oil content $(57 \%)$ as well as a very high rate of oleic acid $(55 \%)$ against a moderate content of tocopherols-totals $(<500 \mathrm{mg} / \mathrm{kg})$ with the lowest rate of linoleic acid and stearic acid respectively $28 \%$ and $3 \%$. On the other hand, the third cluster is represented by 3 genotypes (O-5, O-7, and $\mathrm{CH}-5)$, which are characterized by a high percentage of palmitic acid (up to $17 \%$ ) and a moderate to a high content of total tocopherols (480 to $500 \mathrm{mg} / \mathrm{kg}$ ).

The fourth cluster is composed of 2 genotypes from Oujda (O-6, O-8), these genotypes have the highest values of linoleic acid (35-36\%). The two genotypes constituting the fifth group $(\mathrm{O}-4, \mathrm{O}-3)$ are characterized by a very low oil content $(<49 \%)$ and a very low content of $\gamma$-tocopherols $(<300 \mathrm{mg} / \mathrm{kg})$, as well as a high percentage of stearic acid.

Regarding the sixth cluster, which includes 4 genotypes (CH-3, CH-6, AG-1, and AG-2), this cluster is characterized by a low level of linoleic acid $(29 \%)$ and a content of total tocopherols below $400 \mathrm{mg} / \mathrm{kg}$.

Finally, the HCA analysis has identified similar genotypes of the 2 regions where the argan tree grows wild (Cluster 6: $\mathrm{CH}-3, \mathrm{CH}-6, \mathrm{AG}-1, \mathrm{AG}-2)$, And 2 introduced genotypes (O-1, $\mathrm{O}-2$,) was found to have a comparable composition and oil content to the argan grown in Beni-Znassen (CH-1, $\mathrm{CH}-4)$ and have been grouped in the same cluster. While the genotype $\mathrm{CH}-2$ was found to have the best oil and oleic acid yield.

\subsection{Statistical correlation}

Table 7 presents the statistical correlation between the fatty acids, and tocopherols found in the chemical composition of the oil, and the climatic parameters recorded during the 6 months before fruits harvesting of the three studied areas 

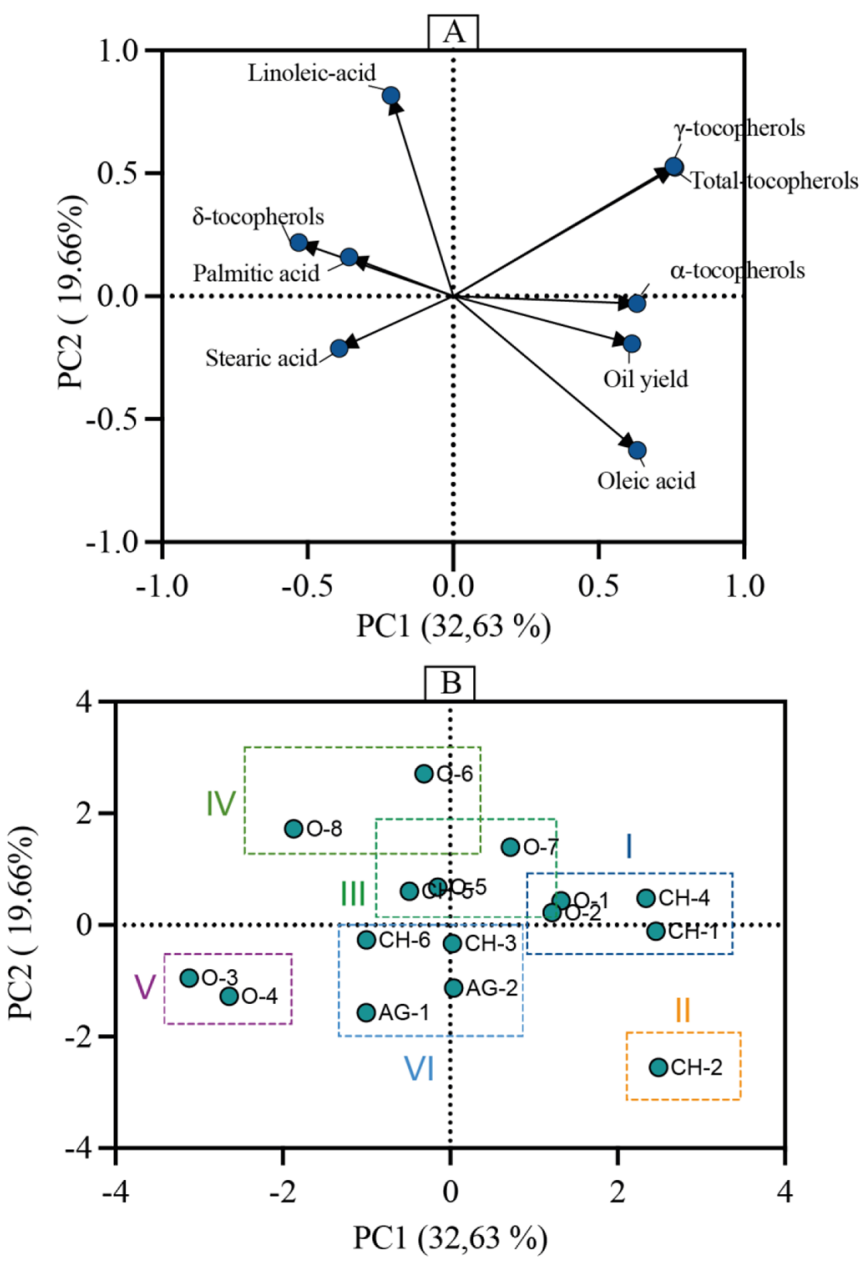

Fig. 4. Graphical representation of principal component analysis of chemical composition argan oil. (A) 2D distribution of variables and (B) 2D genotypes distribution.

(Oujda, Beni-Znassen, Anti-atlas), also the altitude was taken into consideration.

The collected results indicated the existence of a statistical correlation between almost all of the studied parameters.

The $\mathrm{T}$ max registered correlated negatively with the $\delta$-tocopherol content, total tocopherols content $(p<0.05)$, and the linoleic acid $(p<0.01)$, and found to correlate positively with the percentage of stearic acid $(p<0.01)$. On the other side, the $\mathrm{T}$ min noted correlated negatively with the $\delta$-tocopherol content, and also with the percentage of the linoleic acid $(p<0.01)$, and positively with the Oleic acid $(p<0.01)$ and the $\alpha$-tocopherols $(p<0.05)$. Concerning the precipitations (PPT), a positive correlation was observed with the $\gamma$-tocopherols, $\delta$-tocopherols, total tocopherols content $(p<0.05)$, and the linoleic acid $(p<0.01)$, on the other part, a negative correlation was observed with the stearic acid $(p<0.01)$. The mean temperature (TAVE) correlated negatively with the $\delta$-tocopherols content, the linoleic acid content, and positively with the oleic and stearic acids $(p<0.01)$.

Regarding the altitude, a low correlation with the different compounds except for a positive correlation with linoleic acid and a negative one with oleic acid $(p<0.01)$, which indicated that the linoleic acid percentage increases with the increase of the altitude, while the oleic acid decreases with the increase of this latter.

\section{Discussion}

In the present study, we have proceeded to an evaluation of the physicochemical quality and chemical composition of the different oils produced by the different genotypes in three regions of Morocco.

Regarding the physio-chemical quality of the extracted oils, it was observed that there is a significant difference between the genotypes, this finding was reported by several studies that indicated that the physicochemical quality of the oil varies according to several factors such as genotype, origin, harvest date, and extraction temperature (Seiquer et al., 2015; El Kharrassi et al., 2018; Mechqoq et al., 2021b; Ouchbani et al., 2021). Concerning the specific extinction $(232 \mathrm{~nm}, 272$, and $\Delta \mathrm{K})$ and peroxide index, results registered by the different samples were inferior to the limit fixed by the national norm related to the argan extra virgin oil (NM 08.5.090) and the same for the acidity index (Moroccan Standard, 2003; Rahmani, 2005). These different parameters enable the measurement of the primary and secondary oxidation compounds such as the conjugated dienes and trienes (Ouchbani et al., 2021), and the presence of these elements in high quantities prove the low quality of the samples and it is translated by a low aptitude for conservation (Boulfane et al., 2015).

Concerning the fatty acids profile, the GC-MS analysis of the methyl esters indicated the presence of four principal fatty acids in the different tested samples. These compounds are mainly predominated with oleic acid, followed by linoleic, palmitic acids, and finally the stearic acid. These results were in accordance with those reported in previous studies (Gharby et al., 2011; Taribak et al., 2013; El Kharrassi et al., 2018; Zaaboul et al., 2018), who have confirmed that oleic acid is a fatty acid abundant in the argan oil (43.1-57.0\%) followed by linoleic acid (29.30-36.00\%), palmitic acid (5.00-15.0\%) and finally the stearic acid (4.30-12\%). Other fatty acids were detected as a trace by Kharbach et al. $(2018,2019)$ such as linolenic acid, arachidic acid, and myristic acid. On the other side, our results are in contradiction with the results obtained by El Adib et al. (2015) who have found that the level of linoleic acid is higher than that of oleic acid.

The PCA showed that the oleic acid correlated negatively with the linoleic and palmitic acids, which means that the elevation of the first is related to the decrease of the second or the opposite. These results are in accordance with the results published by Chergui et al. (2021), who have demonstrated that the level of oleic acid increases according to the maturity of the fruits. The difference in fatty acid composition observed between the different genotypes could be explained by a difference in fruits maturity. In fact, Chergui et al. (2021) have observed a difference in the precocity of flowering and therefore in the ripening of the fruits. On the other hand, this finding seems to be natural regarding the biosynthesis way of the long-chain fatty acids in the oleaginous plants, which starts with palmitic acid converted to stearic acid under the effect of elongation. After that the stearic acid is converted to oleic acid 


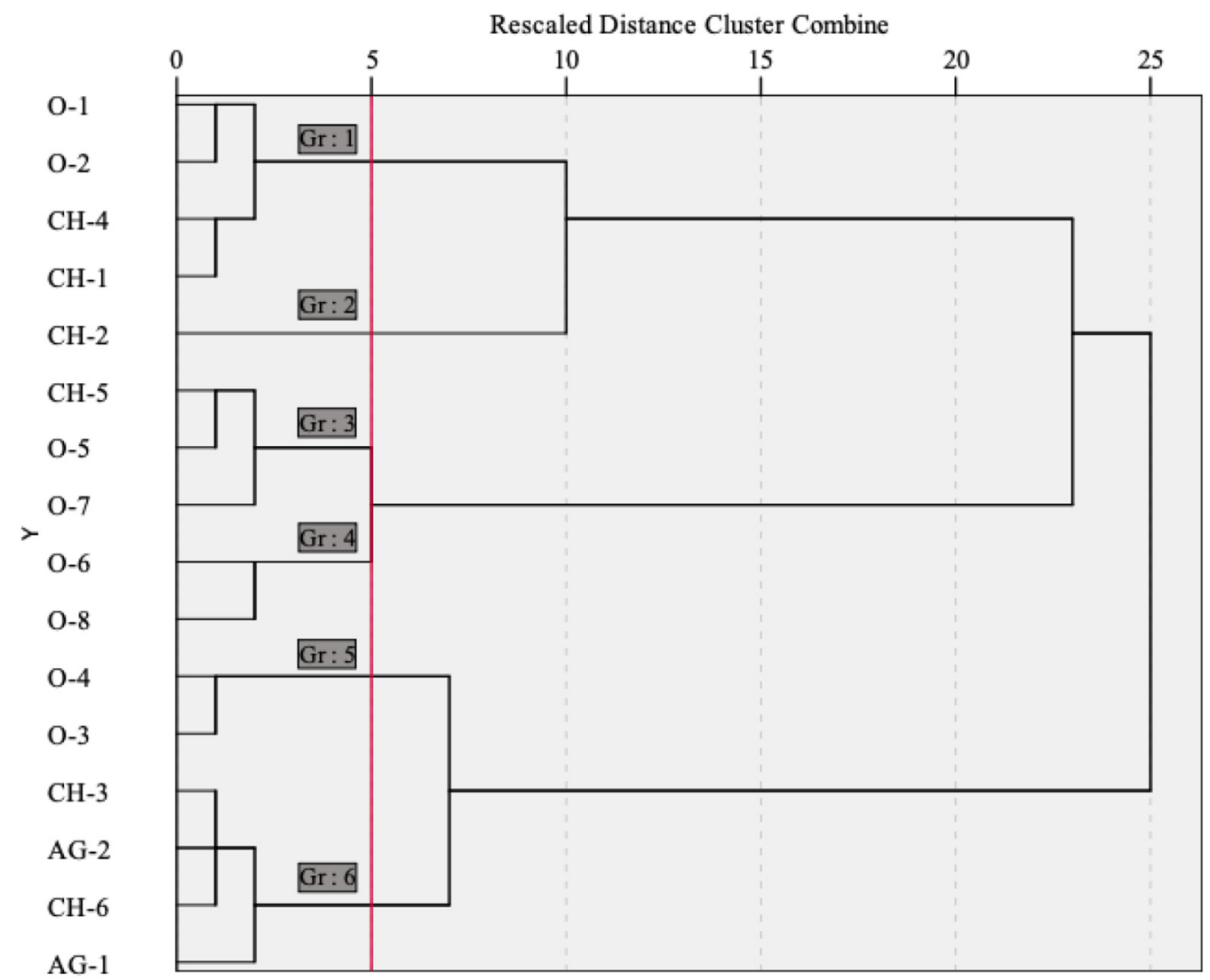

Fig. 5. Dendrogram of different argan genotypes produced by the hierarchical cluster analysis.

Table 7. Correlation matrix between the climatic and chemical settings.

\begin{tabular}{lllllllllll}
\hline & $\begin{array}{l}\alpha- \\
\text { tocopherols }\end{array}$ & $\begin{array}{l}\gamma- \\
\text { tocopherols }\end{array}$ & $\begin{array}{l}\delta- \\
\text { tocopherols }\end{array}$ & $\begin{array}{l}\text { Total- } \\
\text { tocopherols }\end{array}$ & $\begin{array}{l}\text { Palmitic } \\
\text { acid }\end{array}$ & $\begin{array}{l}\text { Linoleic } \\
\text { acid }\end{array}$ & $\begin{array}{l}\text { Oleic } \\
\text { acid }\end{array}$ & $\begin{array}{l}\text { Stearic } \\
\text { acid }\end{array}$ & Unsaturated & Saturated \\
\hline TMAX & -0.026 & -0.345 & $-0.344^{*}$ & $-0.366^{*}$ & -0.052 & $-0.435^{* *}$ & 0.003 & $0.667^{* *}$ & $-0.398^{* *}$ & $0.398^{* *}$ \\
TMIN & $0.311^{*}$ & 0.09 & $-0.48^{* *}$ & 0.073 & -0.288 & $-0.529 * *$ & $0.482^{* *}$ & 0.23 & 0.081 & -0.0814 \\
PPT & 0.024 & $0.344^{*}$ & $0.346^{*}$ & $0.364^{*}$ & 0.0548 & $0.438^{* *}$ & -0.006 & $-0.667 * *$ & $0.397 * *$ & $-0.397 * *$ \\
TAVE & 0.264 & -0.028 & $-0.528^{* *}$ & -0.049 & -0.269 & $-0.599^{* *}$ & $0.424^{* *}$ & $0.410^{* *}$ & -0.053 & 0.0532 \\
Altitude & -0.196 & -0.06 & 0.304 & -0.049 & 0.265 & $0.405^{* *}$ & $-0.394^{* *}$ & -0.186 & -0.091 & 0.091 \\
\hline
\end{tabular}

Values followed by $* P<0.05$ and $* * P<0.01$.

using $\Delta 9$-desaturase and finally using $\Delta 12$-desaturase the oleic acid is converted to linoleic acid. All this means that the increase of each fatty acid implies the decrease of its precursor (Metougui, 2017).

The tocopherols exist naturally in four forms $\alpha, \beta, \gamma$, $\delta$-tocopherols, and are characterized by a high antioxidant activities which play a crucial role in the anti-stress mechanisms of the plant, meanwhile the presence of these compounds contribute to the conservation of the oil (Rey et al., 2021), and the preservation of the integrity of the cell membrane and its components against various types of stress (Sadiq et al., 2019).

Argan oil is very well known for its richness in tocopherols, especially the $\gamma$-tocopherols (Charrouf and
Guillaume, 2008). According to the obtained results, the $\gamma$-tocopherols were the most abundant followed by $\alpha$-tocopherols, and finally the $\delta$-tocopherols. These obtained results are in accordance with the majority of the published studies (Hilali et al., 2005; Matthäus et al., 2010; Gharby et al., 2021; Mouahid et al., 2021). On the other hand, the $\beta$-tocopherols were noted to be present by El Kharrassi et al. (2018) as a trace $(0.12 \%)$.

On the other hand, the total tocopherols content was ranging from 323.86 and $553.12 \mathrm{mg} / \mathrm{kg}$ according to the genotype and the origin. These results were in accordance with the results of Matthäus et al. (2010) and Hilali et al. (2005) who have indicated that total tocopherols content varies between 334.7 and $457.1 \mathrm{mg} / \mathrm{kg}$ and between 400 and 
$775 \mathrm{mg} / \mathrm{kg}$, respectively. Mouahid et al. (2021) have demonstrated also that the total tocopherols content of the argan oils extracted using the Soxhlet apparatus were ranging from 412 to $553 \mathrm{mg} / \mathrm{kg}$.

However, it was lower than that mentioned in Gharby et al. (2021)'s study, which has indicated that argan oil tocopherols content was ranging between 649 and $766 \mathrm{mg} / \mathrm{kg}$ and that of Taribak et al. (2013) with total tocopherols content of $637 \mathrm{mg} / \mathrm{kg}$. This difference could be due to, the method of extraction used, kernels pretreatment (Mouahid et al., 2021) and genotypes effect. This indicates that different settings could influence the total tocopherols content such as high temperature and intense light (Spicher et al., 2016).

The variance analysis showed the existence of a significant difference between the tested samples, which indicated that the argan oil is endowed with an important diversity which was similar to the results obtained by Aithammou et al. (2019) and Ait Aabd et al. (2013) who have mentioned that the argan tree is characterized by a very high genetic diversity and that the effect of the clone is very marked on the chemical characteristics of oils produced.

The genotype effect is not only responsible for the chemical composition but also the origin and the climatic conditions are influencing the chemical composition of the oil (El Monfalouti et al., 2020). Our results indicated that the climatic parameters correlated significantly with the chemical composition. Similarly, Nerd et al. (1994) evaluated the chemical characteristics of argan oil produced in two desert locations in Israel, as well as the work of El Monfalouti et al. (2020) who have mentioned that the climate has affected the amount of triglycerides while the other parameters have not presented any difference between regions. In the same context Elgadi et al. (2021a) have demonstrated that the fatty acids composition was influenced by the altitude and latitude, a high percentage of the linoleic acid was a marker of coastal argan oil, while the high content of palmitic acid was considered to be the marker of continental argan oil. On the other hand Elgadi et al. (2021b) have shown that the tocopherols content of argan oil is strongly influenced by origin, the distance from the coast, and altitude. Finally, Kharbach et al. (2018, 2019) have allowed a geographical classification of argan oils according to chemical composition.

\section{Conclusion}

As a preliminary study, our results indicated that the trees introduced in Oujda City have shown a chemical composition similar to that of argan oils produced in its natural domain (Agadir and Chouihya). The majority of argan trees introduced in Oujda City have shown an important quantity of total tocopherols content higher than $500 \mathrm{mg} / \mathrm{kg}$, as well as a rate of oleic acid up to $49.31 \%$, and unsaturated fatty acid $(81.79 \%)$. This evokes the plasticity of the argan tree to the climatic conditions of Oujda City. On the other hand, our study has showed that the argan tree is characterized by a significant variability, which can be exploited in the selection of subjects according to their areas of use. In the same sense, the adaptation of the argan tree to other regions differing in their environmental conditions will undoubtedly help to contribute to the protection and sustainability of the argan grove in
Morocco. Finally, further studies are needed to confirm these results, such as the chemical composition stability over the years, the effect of the climatic change and the interaction between genotype and environment.

Acknowledgments. The authors are sincerely thankful to Pr. Serghini-Caid Hana for carrying out the HPLC analysis at the Laboratory of Agricultural Production Improvement, Biotechnology and Environment (LAPIBE), Department of Biology, Faculty of Sciences, University of Mohammed First, Oujda, Morocco.

Conflicts of interest. The authors declare no conflicts of interest.

\section{Funding}

This study received no funding.

\section{References}

Abatzoglou JT Dobrowski SZ, Parks SA, Hegewisch KC. 2018. Terra Climate, a high-resolution global dataset of monthly climate and climatic water balance from 1958-2015. Sci Data 5(1): 1-12.

Ait Aabd N, El Asbahani A, El Alem Y, El Finti A, Msanda F, El Mousadik A. 2013. Variation in oil content and fatty acid composition in preselected argan trees with morphological characters and geographical localization. Mediterr J Nutr Metab 6(3): 217-225. https://doi.org/10.1007/s12349-013-0134-2.

Aithammou R, Harrouni C, Aboudlou L, et al. 2019. Effect of clones, year of harvest and geographical origin of fruits on quality and chemical composition of argan oil. Food Chem 297: 124749. https://doi.org/10.1016/j.foodchem.2019.05.024.

Alimentarius Codex. 1999. Codex standard for named vegetable oils. Codex Stand 210: 1-13.

Ben Moumen A, Mansouri F, Richard G, et al. 2015. Variations in the phytosterol and tocopherol compositions and the oxidative stability in seed oils from four safflower (Carthamus tinctorius L.) varieties grown in north-eastern Morocco. Int J Food Sci Technol 50(10): 2264-2270. https://doi.org/10.1111/ijfs.12879.

Bellefontaine R, Ferradous A, Alifriqui M, Monteuuis O. 2010. Multiplication végétative de l'arganier, Argania spinosa, au Maroc : le projet John Goelet. Bois Trop 304: 47. https://doi.org/ 10.19182/bft2010.304.a20446.

Boukhobza M, Pichon-Prun N. 1988. L'arganier ressource économique et médicinale pour le Maroc. Phytothérapie 27: 21-26.

Boulfane S, Maata N, Anouar A, Hilali S. 2015. Caractérisation physicochimique des huiles d'olive produites dans les huileries traditionnelles de la région de la Chaouia-Maroc. J App Biosci 87 (1): 8022. https://doi.org/10.4314/jab.v87i1.5.

Charrouf Z, Guillaume D. 2008. Argan oil: Occurrence, composition and impact on human health. Eur J Lipid Sci Technol 110(7): 632-636.

Charrouf Z, Guillaume D. 2010. Should the amazigh diet (regular and moderate argan-oil consumption) have a beneficial impact on human health? Crit Rev Food Sci Nutr 50(5): 473-477. https:// doi.org/10.1080/10408390802544520.

Charrouf Z, Guillaume D, Driouich A. 2002. The argan tree, an asset for Morocco. Biofutur (France).

Chaussod R, Adlouni A, Christon R. 2005. L'arganier et 1'huile d'argane au Maroc: vers la mutation d'un système agroforestier traditionnel? Cahiers Agricultures 14(4): 6. 
Chergui A, Hafid LE, Ajal EA, et al. 2021. Evolution of biometric parameters and oil fatty acid composition of argan "Argania spinosa L. Skeels" fruits from Beni-Znassen (Eastern Region of Morocco) during ripening. Pharmacogn J 13(2): 296-308. https:// doi.org/10.5530/pj.2021.13.39.

Daoudi NE, Bouhrim M, Ouassou H, et al. 2020. Inhibitory effect of roasted/unroasted Argania spinosa seeds oil on $\alpha$-glucosidase, $\alpha$-amylase and intestinal glucose absorption activities. South Afr J Bot 135: 413-420. https://doi.org/10.1016/j.sajb.2020.09.020.

Drissi A, Bennani H, Giton F, Charrouf Z, Fiet J, Adlouni A. 2006. Tocopherols and saponins derived from Argania spinosa exert, an antiproliferative effect on human prostate cancer. Cancer Invest 24(6): 588-592. https://doi.org/10.1080/07357900600894815.

El Adib S, Aissi O, Charrouf Z, Ben Jeddi F, Messaoud C. 2015. Argania spinosa var. mutica and var. apiculata: Variation of fattyacid composition, phenolic content, and antioxidant and a-amylase-inhibitory activities among varieties, organs, and development stages. Chem Biodivers 12(9): 1322-1338. https:// doi.org/10.1002/cbdv.201400328.

El Kharrassi Y, Maata N, Mazri MA, et al. 2018. Chemical and phytochemical characterizations of argan oil (Argania spinosa L. Skeels), olive oil (Olea europaea L. cv. Moroccan picholine), cactus pear (Opuntia megacantha salm-dyck) seed oil and cactus cladode essential oil. Food Meas 12(2): 747-754. https://doi.org/ 10.1007/s11694-017-9688-x.

El Monfalouti H, Kartah BE, Hilali M. 2020. Evaluation of the chemical composition of argan (Argania spinosa L.) oil according to its extraction method, origin of production and altitude. JWPR 10(3): 111-118. https://doi.org/10.36380/scil.2020.ojafr15.

Elgadi S, Ouhammou A, Taous F, et al. 2021a. Combination of stable isotopes and fatty acid composition for geographical origin discrimination of one argan oil vintage. Foods 10(6): 1274. https://doi.org/10.3390/foods 10061274.

Elgadi S, Ouhammou A, Zine H, et al. 2021b. Discrimination of geographical origin of unroasted kernels argan oil (Argania spinosa L. Skeels) using tocopherols and chemometrics. Durazzo A, ed. J Food Qual 2021: 1-9. https://doi.org/10.1155/2021/ 8884860 .

Faouzi K, Rharrabti Y, Boukroute A, Mahyou H. 2014. Cartographie de l'aire de répartition de l'arganier (Argania spinosa L. Skeels) dans la région orientale du Maroc par le G.P.S. combiné au S.I.G.C.: 10 .

Gharby S, Harhar H, Kartah B, Monfalouti HE. 2011. Analyse chimique et sensorielle de l'huile d'argane. Les technologies de Laboratoire 6: 11.

Gharby S, Guillaume D, Nounah I, et al. 2021. Shelf-life of Moroccan prickly pear (Opuntia ficus-indica) and argan (Argania spinosa) oils: A comparative study. Grasasaceites 72(1): e397. https://doi. org/10.3989/gya.1147192.

Hilali M, Charrouf Z, Aziz Soulhi AE, Hachimi L, Guillaume D. 2005. Influence of origin and extraction method on argan oil physico-chemical characteristics and composition. J Agric Food Chem 53(6): 2081-2087. https://doi.org/10.1021/jf040290t.

Kamal R, Kharbach M, Vander Heyden Y, et al. 2019. In vivo antiinflammatory response and bioactive compounds' profile of polyphenolic extracts from edible argan oil (Argania spinosa L.), obtained by two extraction methods. J Food Biochem 43(12). https://doi.org/10.1111/jfbc.13066.

Kamal R, Kharbach M, Heyden YV, et al. 2021. In vitro and in vivo anti-hyperglycemic potential of saponins cake and argan oil from Argania spinosa. Foods 10(5): 1078. https://doi.org/10.3390/ foods 10051078 .
Kharbach M, Kamal R, Mansouri MA, et al. 2018. Selected-ion flowtube mass-spectrometry (SIFT-MS) fingerprinting versus chemical profiling for geographic traceability of Moroccan argan oils. Food Chem 263: 8-17. https://doi.org/10.1016/j.food chem.2018.04.059.

Kharbach M, Kamal R, Marmouzi I, et al. 2019. Fatty acid profiling vs. UV-visible fingerprints for geographical classification of Moroccan argan oils. Food Contr 95: 95-105. https://doi.org/ 10.1016/j.foodcont.2018.07.046.

Marfil R, Giménez R, Martínez O, et al. 2011. Determination of polyphenols, tocopherols, and antioxidant capacity in virgin argan oil (Argania spinosa, Skeels). Eur J Lipid Sci Technol 113(7): 886-893. https://doi.org/10.1002/ejlt.201000503.

Matthäus B, Guillaume D, Gharby S, Haddad A, Harhar H, Charrouf Z. 2010. Effect of processing on the quality of edible argan oil. Food Chem 120(2): 426-432. https://doi.org/10.1016/j.food chem.2009.10.023.

Mechqoq H, El Yaagoubi M, El Hamdaoui A, et al. 2021a. Ethnobotany, phytochemistry and biological properties of argan tree (Argania spinosa L. Skeels) (Sapotaceae)-A review. J Ethnopharmacol 281: 114528. https://doi.org/10.1016/j. jep.2021.114528.

Mechqoq H, El Yaagoubi M, Momchilova S, Msanda F, El Aouad N. $2021 \mathrm{~b}$. Comparative study on yields and quality parameters of argan oils extracted by conventional and green extraction techniques. Grain Oil Sci Technol 4(3): 125-130. https://doi. org/10.1016/j.gaost.2021.08.002.

Metougui ML. 2017. Étude de la variabilité agro-morphologique de la population d'arganier (Argania spinosa L. Skeels) d'Admine et contribution à la domestication de l'espèce. Maroc: Institut Agronomique et Vétérinaire Hassan II.

Mohammed F, Guillaume D, Warland J, Abdulwali N. 2021. Analytical methods to detect adulteration of argan oil: A critical review. Microchem J: 106501.

Moroccan Standard. 2003. 08.5.090. Huiles d'argane. Spécifications. Service de Normalisation Industrielle Marocaine (SNIMA) Ministère de l'Industrie, du Commerce et des Télécommunications.

Mouahid A, Bombarda I, Claeys-Bruno M, et al. 2021. Supercritical $\mathrm{CO}_{2}$ extraction of Moroccan argan (Argania spinosa L.) oil: Extraction kinetics and solubility determination. $\mathrm{J} \mathrm{CO}_{2}$ Util 46: 101458. https://doi.org/10.1016/j.jcou.2021.101458.

Moukal A. 2004. L'arganier, Argania spinosa L. (Skeels), usage thérapeutique, cosmétique et alimentaire. De la Recherche à la Pratique 2(5): 135-141. https://doi.org/10.1007/ s10298-004-0041-2.

Moukrim S, Lahssini S, Alaoui HM, Rifai N, Arahou M, Rhazi L. 2018. Modélisation de la distribution spatiale des espèces endémiques pour leur conservation: cas de l'Argania spinosa L. Revue d'Écologie, Terre et Vie, Société nationale de protection de la nature 73: 14.

Nerd A, Eteshola E, Borowy N, Mizrahi Y. 1994. Growth and oil production of argan in the Negev Desert of Israel. Ind Crops Prod 2(2): 89-95. https://doi.org/10.1016/0926-6690(94)90089-2.

Organisation Internationale de Normalisation. 2002. Corps gras d'origines animale et végétale. Détermination de l'absorbance dans l'ultraviolet, exprimée sous la forme d'extinction spécifique en lumière ultraviolette.

Ouchbani T, Bennis M, Khaili A, Zahar M, Nakajima M. 2021. Effects of the heating temperature during the press extraction process on the yield and quality of cosmetic argan oil. EuroMediterr J Environ Integr 6(1): 11. https://doi.org/10.1007/ s41207-020-00224-5. 
Rahmani M. 2005. Composition chimique de l'huile d'argane «vierge». Cahiers Agricultures 14: 5.

Rammal H, Bouayed J, Younos C, Soulimani R. 2009. Notes ethnobotanique et phytopharmacologique d'Argania spinosa L. Phytothérapie 7(3): 157-160. https://doi.org/10.1007/ s10298-009-0386-7.

Rey F, Rodrigo MJ, Zacarias L. 2021. Accumulation of tocopherols and transcriptional regulation of their biosynthesis during cold storage of mandarin fruit. Postharv Biol Technol 180: 111594. https://doi.org/10.1016/j.postharvbio.2021.111594.

Sadiq M, Akram NA, Ashraf M, Al-Qurainy F, Ahmad P. 2019. Alpha-tocopherol-induced regulation of growth and metabolism in plants under non-stress and stress conditions. J Plant Growth Regul 38(4): 1325-1340. https://doi.org/10.1007/ s00344-019-09936-7.

Seiquer I, Rueda A, Olalla M, Cabrera-Vique C. 2015. Assessing the bioavailability of polyphenols and antioxidant properties of extra virgin argan oil by simulated digestion and Caco-2 cell assays. Comparative study with extra virgin olive oil. Food Chem 188: 496-503. https://doi.org/10.1016/j.foodchem.2015.05.006.

Spicher L, Glauser G, Kessler F. 2016. Lipid antioxidant and galactolipid remodeling under temperature stress in tomato plants. Front Plant Sci 7. https://doi.org/10.3389/fpls.2016.00167.

Taribak C, Casas L, Mantell C, ElfadliZ, Metni RE, Martínez de la OssaEJ. 2013. Quality of cosmetic argan oil extracted by supercritical fluid extraction from Argania spinosa L. JChem 2013: 1-9. https://doi.org/ 10.1155/2013/408194.

Tazi MR, Berrichi A, Haloui B. 2003. Esquisse cartographique de l'aire de l'arganier Argania spinosa L. Skeels au Maroc nordoriental. Bulletin de l'Institut scientifique 25: 53-55.

Zaaboul F, Raza H, Lazraq A, Deng B, Cao C, Liu YF. 2018. Chemical composition, physical properties, and the oxidative stability of oil bodies extracted from Argania spinosa. J Am Oil Chem Soc 95(4): 485-495. https://doi.org/10.1002/aocs.12053.

Cite this article as: Azizi S, Dalli M, Mzabri I, Berrichi A, Gseyra N. 2022. Chemical characterization of oils produced by some native and introduced genotypes of argan tree in Eastern Morocco using HPLC-DAD/GC-MS, and the evaluation of their physicochemical parameters. OCL 29: 14 . 